Pak. j. sci. ind. res. Ser. B: biol. sci. 201255 (2) 108-113

\title{
Modified Protocol for Genomic DNA Extraction from Newly Plucked Feathers of Lophura leucomelana hamiltoni (Galliformes) for Genetic Studies and its Endo-restriction Analysis
}

\author{
Saiqa Andleeb ${ }^{a *}$, Sara Shamim ${ }^{a}$, Muhammad Naeem Awan ${ }^{b}$ and Riaz Aziz Minhas ${ }^{\text {a }}$ \\ a'Department of Zoology, University of Azad Jammu and Kashmir, Muzaffarabad, Pakistan \\ bProgram for Mountain Areas Conservation (PMAC), Regional Office Muzaffarabad, \\ AJK - 13100, Ministry of Environment, Pakistan
}

(received July 26, 2011; revised February 2, 2012; accepted April 26, 2012)

\begin{abstract}
A rapid and accurate protocol was used first time to isolate the high-quality genomic DNA from newly plucked feathers of Lophura leucomelana. Two different lysis protocols were used depending on the feather size and it was observed that $55{ }^{\circ} \mathrm{C}$ for 3 to 4 days showed better results of feathers lysis as compared with the $37{ }^{\circ} \mathrm{C}$ for overnight with gentle shaking. Purification of genomic DNA was also performed with phenol: chloroform: isoamyl alcohol and 100\% absolute ethanol precipitation methods. By using this protocol, a significant amount of high-quality genomic DNA was obtained and the purity of DNA was analyzed through endo-restriction analysis. Genomic DNA isolated with this modified method will be used for Southern blotting and also in several polymerase chain reaction systems devoted to sex determination and paternity testing and the evolutionary relationships among the other pheasants.
\end{abstract}

Keywords: Agarose gel electrophoresis, genomic DNA extraction, Lophura leucomelana hamiltoni, endo-restriction analysis

\section{Introduction}

The White Kalij (Lophura leucomelana hamiltoni), is a pheasant found in forests and thickets, especially in the foothills, from the Indus River to western Thailand (McGowan and Panchen, 1994). Lophura leucomelana has nine sub-species and Lophura leucomelana hamiltoni is the species found in Pakistan (Johnsgard, 1999; 1986). The speciation pattern in genus Lophura is certainly the most complex of any in all pheasant groups, and has been cause of a vast number of species and subspecies being described, many of which have been based on single specimen (Johnsgard, 1986). The pheasants in Lophura are sexually dimorphic, with unremarkable and mimetic females, although, males also show cryptic plumages in some species. In previous literature, plumage trait has been used to conclude the evolutionary relationships and taxonomy of the pheasants (Johnsgard, 1986; Delacour, 1977). On the other hand, Kimball et al. (1999) demonstrated that most of these phenotypic traits were not diagnostic and might be evolved repeatedly and independently among the pheasants.

In previous literature it has been shown that the DNA was extracted from the mammals, which are often difficult to capture like bears, wolves, primates, elephants

*Author for correspondence; E-mail: drsaiqa@gmail.com
(Hausknecht et al., 2007; Schmaltz et al., 2006; McGrew et al., 2004; Eggert et al., 2003; Morin et al., 2001). Similarly, DNA has also been sampled from hair, faeces, urine, fish scales, shed snake skin, and egg shells (Hausknecht et al., 2007; Lucentini et al., 2006; Schmaltz et al., 2006; Eguchi and Eguchi, 2000; Nota and Takenaka, 1999; Goossens et al., 1998; Bricker et al., 1996; Tikel et al., 1996) and can widely be used for sex identification and genetic disease diagnosis, respectively. In the same way, in present research work the genomic DNA extraction was carried out from the newly plucked feathers of White Crested Kalij pheasant instead of blood that is necessary to diminish the stress on the birds because in case of juvenile birds and small parrots the blood vessels are in small size that makes the blood extraction very difficult (Natalia et al., 2001; Hauge, 1997; Alleman, 1996; Davidson et al., 1986).

The evolutionary relationships and the taxonomy of the subspecies of the silver and Kalij pheasants (Lophura nycthemera and L. leucomelanos; Phasianidae) are unclear. Delacour (1949) included them in a single superspecies, and pointed out the following systematic problems: (i) their description in a large number of genera before his revision, 49 taxa of silver and Kalij pheasants being split into 28 species belonging to four genera (Del Hoyo et al., 1994); (ii) their large geographical 
range with a limited number of specimens available to study; (iii) the occurrence of natural hybridization in contact zones where population of the two species of his new classification overlapped. Therefore, Delacour (1949) suggested that some subspecies could have derived from past episodes of hybridization. About 15 subspecies of L. nycthemera and nine subspecies of L. leucomelana are currently recognized (Johnsgard, 1999; Del Hoyo et al., 1994). Recently, it has been shown that the population of Kalij pheasants are going to decline from the foothills of Pakistan and no research work was done regarding to the social, biological and ecological behavior of foothill pheasants. On the other hand the number of adults and chicks of Kalij pheasant were grown in the Dhodial Pheasantry from 2000, to prevent the population of the Kalij pheasant.

On the basis of these critical points, some questions come up in mind that why the population of Kalij pheasants are going to be declined? Either it is an effect of hybridization or may be due to environmental effects? Are the silver pheasant species overlapping with the Kalij pheasants? So, in the current study, the newly plucked feathers of Lophura leucomelana hamiltoni, were collected and instead of blood were used first time as a source of genomic DNA in Biotechnology Lab., Department of Zoology, University of Azad Jammu and Kashmir (AJK), Muzaffarabad and we are trying to identify the genes that related to enhance the growth and the population of Kalij pheasant and to determine the evolutionary relationship among the silver and Kalij pheasant. Our goals were associated to, how much DNA can be recovered from the newly plucked feathers, optimization of DNA extraction method for feathers through electrophoretic technique, and to test the effects of feather type (size) on DNA yield.

\section{Materials and Methods}

Sampling. Feather samples of White Crested Kalij pheasant were collected from Pattika Captive Breeding Center and different sizes of 30 feathers were plucked. Fresh plucked and some old feather samples were stored in $100 \%$ absolute ethanol at room temperature for two weeks or at $4{ }^{\circ} \mathrm{C}$ for two months to isolate high-quality genomic DNA and to avoid the DNA degradation and bacterial contamination (Randi and Lucchini, 1998; Gerloff et al., 1995, Taberlet and Bouvet, 1991).

DNA extraction. Before the isolation of genomic DNA the feathers were washed with $70 \%$ ethanol and later with $\mathrm{d}_{3} \mathrm{H}_{2} \mathrm{O}$. A 0.5 to $1 \mathrm{~cm}$ section was cut from the terminal portion of the feather calamus and placed in a $1.5 \mathrm{~mL}$ Eppendorf tube containing $5 \mathrm{~mL}$ of lysis buffer (50 mM Tris-HCl, pH 8; 20 mM EDTA, pH 8; 2\% sodium dodecyl sulfate; and $175 \mathrm{mg} / \mathrm{mL}$ proteinase $\mathrm{K}$ ). Lysis temperatures and incubation times were different i.e at $37^{\circ} \mathrm{C}$ to $55^{\circ} \mathrm{C}$, depending on the feather size for overnight to several hours with gentle shaking (Nattalia et al., 2001). After the lysis step, samples were vigorously vortexed to homogenize the lysate and then centrifuged at 13,000 rpm for $10 \mathrm{~min}$ if non digested soft tissue was present. The supernatant was transferred to a clean $1.5 \mathrm{~mL}$ Eppendorf tube, and DNA was purified with $500 \mu \mathrm{L}$ of phenol: chloroform: isoamyl alcohol (25: 24:1). Subsequently, $50 \mathrm{~mL}$ of $2 \mathrm{M} \mathrm{NaCl}$ and 2 volumes of $100 \%$ absolute ethanol were used to precipitate the genomic DNA. To maximize DNA recovery, this step can be performed at $-20{ }^{\circ} \mathrm{C}$ for overnight. Next day DNA recovery was taken by centrifugation at 13,000 rpm for $10 \mathrm{~min}$. The DNA pellet was washed in 70\% ethanol. The pellet was finally air dried and re-suspended in $\mathrm{d}_{3} \mathrm{H}_{2} \mathrm{O}$ and stored at $-20{ }^{\circ} \mathrm{C}$.

Agarose gel electrophoresis. Isolated DNA was analyzed by $2 \%(\mathrm{w} / \mathrm{v})$ gel in a small electrophoresis apparatus $(6 \times 10 \times 0.5 \mathrm{~cm}) .0 .5 \mathrm{~g}$ of agarose (Eurogentec) was melted in $50 \mathrm{~mL}$ of $1 \mathrm{X}$ TBE buffer ( $55 \mathrm{~g}$ of Boric acid, $1 \mathrm{M}$ of EDTA, $108 \mathrm{~g}$ of Tris per liter of distilled water (Andleeb et al., 2010a; 2010b) in a microwave oven until a clear, transparent solution was achieved. After cooling to about $60{ }^{\circ} \mathrm{C}, 0.01 \%(\mathrm{w} / \mathrm{v})$ ethidium bromide was added. The melted agarose was poured into a flat bed gel tray. An appropriate comb was selected for forming the sample wells in the gel. The gel was allowed to set completely at room temperature. The comb was carefully removed and the gel tray was placed in an electrophoresis tank containing sufficient $1 \mathrm{X}$ TBE buffer to just cover the gel. DNA samples were mixed with $1 / 6$ volume (v/v) of $6 \mathrm{X}$ DNA loading buffer. The DNA samples were loaded into the wells of the solidified gel submerged in $1 \mathrm{X}$ TBE and gel electrophoresis was carried out at 50-100 volts until the required DNA separation was achieved. The DNA bands in the gel were visualized using short wave ultraviolet light provided by a trans-illuminator and photographed using a digital camera (EOS 350D; EF-S 18-55, Kit).

Phenol chloroform treatment. The genomic DNA was diluted with $\mathrm{d}_{3} \mathrm{H}_{2} \mathrm{O}$ to $100 \mu \mathrm{L}$. An equal volume of phenol and chloroform (1:1) was added. The mixture was shaken gently and centrifuged for $6 \mathrm{~min}$. The supernatant was taken into a fresh Eppendorf tube and 
$1 / 10^{\text {th }}$ volume of $3 \mathrm{M}$ sodium acetate $(10 \mu \mathrm{L}), \mathrm{pH} 5.4$ and 2.5 volume of absolute ethanol $(250 \mu \mathrm{L})$ were added. The mixture was placed at $-20{ }^{\circ} \mathrm{C}$ for $1 \mathrm{~h}$ and then centrifuged for $10 \mathrm{~min}$. The supernatant was discarded and the pellet was washed with $70 \%$ ethanol. The mixture was centrifuged for $2 \mathrm{~min}$, the supernatant was removed and the pellet was air dried. Finally the pellet was dissolved in $20 \mu \mathrm{L} \mathrm{d}_{3} \mathrm{H}_{2} \mathrm{O}$.

DNA quantification method. A spectrophotometric measurement of the amount of UV irradiation absorbed by nucleic acid (DNA or RNA) is very simple and accurate method. For the spectrophotometric measurement $1 \mu \mathrm{L}$ of isolated DNA was diluted with $99 \mu \mathrm{L}$ of distilled water and the readings taken at a wavelength of 260 and $280 \mathrm{~nm}$ in the sample.

Restriction analysis of isolated genomic DNA. The digestion of genomic DNA was achieved by single and double digestion methods by using specific Pst1, BamHI and HindIII restriction enzymes and their buffers in accordance with the supplier's (Vivantis) guidelines. For restriction, the $20 \mu \mathrm{L}$ reaction mixture contained $\sim 1 \mu \mathrm{g}$ of the genomic DNA and 10 units of restriction enzyme(s) in $1 \mathrm{X}$ or $2 \mathrm{X}$ reaction buffer. The restriction was done by incubating the mixture at $37^{\circ} \mathrm{C}$ (some restrictions enzymes used a slightly different temperature) for overnight. The results of restriction enzyme digestions were examined by electrophoresis on $1 \%$ agarose gel.

Photography and manipulation. A digital camera (EOS 350D; EF-S 18-55, Kit) was used to photographs in the field as well as in the Biotechnology Lab. The same camera was used to take photographs of DNA under ultraviolet (UV) light using a hand held UV lamp (UV semiconductor inspection lamp products, upland, CA; Black Ray model B 100AP). The photographs were manipulated with Adobe Photoshop CS and
Microsoft office picture manager. The figures were produced using CorelDraw 12 and Microsoft Office Powerpoint 2007.

\section{Results and Discussion}

For the large feathers, lysis was performed at $37^{\circ} \mathrm{C}$ for overnight with gentle shaking and small feathers were incubated at $55^{\circ} \mathrm{C}$ for overnight to several days without shaking (Natalia et al., 2001). It was observed that the incubation period of $55^{\circ} \mathrm{C}$ for 3 to 4 days showed better results of feathers lysis as compared with the $37{ }^{\circ} \mathrm{C}$ for overnight with gentle shaking because the lysis buffer effectively solubilizes the cellular proteins but does not liberate genomic DNA (Table 1).

After the lysis step, DNA was purified with phenol: chloroform: isoamyl alcohol (25:24:1) and in later the aqueous phase was treated twice time with phenol: chloroform (25:24) to purify the genomic DNA (Table 1). Subsequently, the maximum recovery of genomic DNA was obtained by using $50 \mu \mathrm{L}$ of $2 \mathrm{M} \mathrm{NaCl}$ and double volumes of $100 \%$ absolute ethanol at $-20^{\circ} \mathrm{C}$ for overnight as compared to the $3 \mathrm{M}$ sodium acetate and propanol. RNAse $(0.1 \mathrm{mg} / \mathrm{mL})$ digestion step was also required for $2-3 \mathrm{~h}$ at $37{ }^{\circ} \mathrm{C}$ in case of large feather or if it contained soft tissue and blood (Natalia et al., 2001; Hauge, 1997; Alleman, 1996; Davidson et al., 1986). It was also noted that the combinations of proteinase $\mathrm{K}, \mathrm{CTAB}$, and repeated extractions with chloroform/isoamyl alcohol were able to remove a substantial amount of contaminating material, especially polysaccharides and proteins, resulting in reliable DNA bands (Fig. 1A and $1 \mathrm{~B}$ and (Table 1). The total amount or quantity of the $50 \mu \mathrm{g}$ genomic DNA was measured at $\mathrm{OD}_{260 \mathrm{~mm}}$ by the absorption of ultra-violet (UV) light by the ring structure of purines and pyrimidines and the quality of the extracted DNA was analyzed through agarose gel electrophoresis
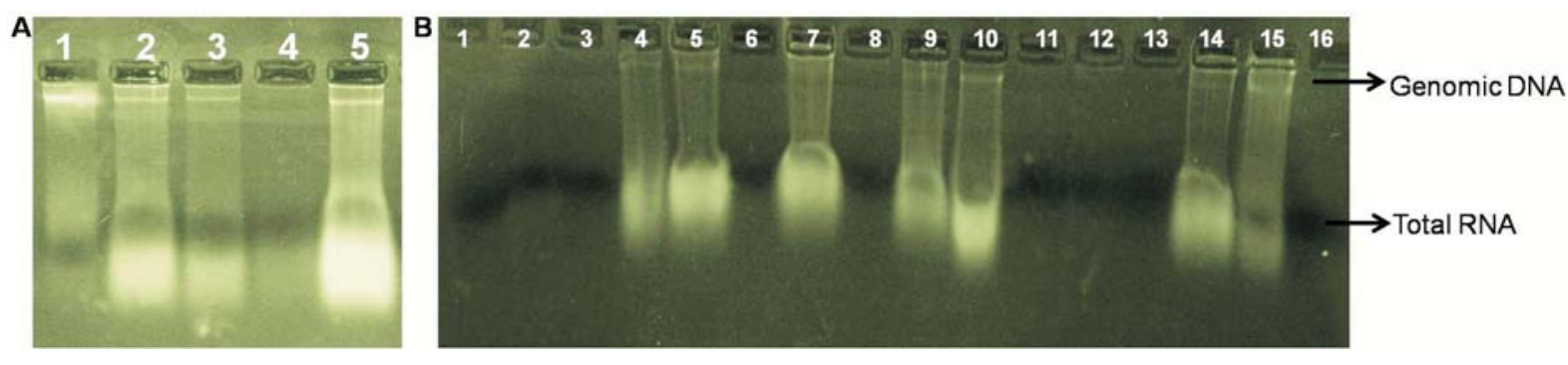

Fig. 1A and 1B. The genomic DNA extraction from different samples of Lophura leucomelana feathers. Genomic DNA and total RNA is clearly observed on $2 \%$ agarose gel electrophoresis. 
(Fig. 1A and 1B). The significant amounts of highquality genomic DNA approx. (50 $\mu \mathrm{g})$ along with the small amounts of non degraded genomic DNA was isolated from the subspecies, White Crested Kalij pheasant
(Fig. 1A and 1B). Moreover, DNA isolated from newly feathers was successfully used to assess the quality of the double stranded DNA through single and double endo-restriction analysis by using specific enzymes

Table 1. Comparison of genomic DNA extraction methods

\begin{tabular}{|c|c|c|c|c|c|c|c|c|}
\hline $\begin{array}{l}\text { Lane no. } \\
\text { on agarose }\end{array}$ & $\begin{array}{l}\text { Feather } \\
\text { size } \\
\text { gel }\end{array}$ & $\begin{array}{l}\text { Incubation } \\
\text { period }\end{array}$ & $\begin{array}{l}\text { Lysis } \\
\text { temperature }\end{array}$ & $\begin{array}{l}2 \% \\
\text { CTAB }\end{array}$ & $\begin{array}{l}\text { Mode of } \\
\text { shaking }\end{array}$ & $\begin{array}{l}\text { 3M sodium } \\
\text { acetate and } \\
\text { propanol }\end{array}$ & $\begin{array}{l}\text { Mixture of } \\
\text { solvents }\end{array}$ & $\begin{array}{l}\text { Quality of } \\
\text { extracted } \\
\text { DNA }\end{array}$ \\
\hline & \multicolumn{8}{|c|}{ Agarose gel A } \\
\hline 1. & Medium & Several days & $55^{\circ} \mathrm{C}$ & Yes & Gentle shaked & Both & A \& B & Good \\
\hline 2. & Medium & Several days & $55^{\circ} \mathrm{C}$ & Yes & Gentle shaked & Both & A \& B & Good \\
\hline 3. & Medium & Several days & $55^{\circ} \mathrm{C}$ & Yes & Gentle shaked & Both & A \& B & Good \\
\hline 4. & Medium & Several days & $55^{\circ} \mathrm{C}$ & Yes & Gentle shaked & Both & A \& B & Poor \\
\hline \multirow[t]{2}{*}{5.} & Medium & Several days & $55^{\circ} \mathrm{C}$ & Yes & Gentle shaked & Both & A \& B & Good \\
\hline & \multicolumn{8}{|c|}{ Agarose gel B } \\
\hline 1. & Medium & $24 \mathrm{~h}$ & $37^{\circ} \mathrm{C}$ & No & Not shaked & Propanol & A & Poor \\
\hline 2. & Medium & $24 \mathrm{~h}$ & $37^{\circ} \mathrm{C}$ & No & Not shaked & Propanol & A & Poor \\
\hline 3. & Medium & $24 \mathrm{~h}$ & $37^{\circ} \mathrm{C}$ & No & Not shaked & Propanol & A & Not detected \\
\hline 4. & Medium & $24 \mathrm{~h}$ & $37^{\circ} \mathrm{C}$ & No & Not shaked & Propanol & A & Poor \\
\hline 5. & Medium & $24 \mathrm{~h}$ & $37^{\circ} \mathrm{C}$ & Yes & Gentle shaked & Propanol & A & Good \\
\hline 6. & Medium & $24 \mathrm{~h}$ & $37^{\circ} \mathrm{C}$ & Yes & Gentle shaked & Propanol & A & Not detected \\
\hline 7. & Medium & $24 \mathrm{~h}$ & $37^{\circ} \mathrm{C}$ & Yes & Gentle shaked & Propanol & A & Good \\
\hline 8. & Control & \multicolumn{7}{|c|}{ Bromophenol blue loading dye } \\
\hline 9. & Medium & $24 \mathrm{~h}$ & $37^{\circ} \mathrm{C}$ & No & Not shaked & $3 \mathrm{M}$ sodium acetate & B & Poor \\
\hline 10. & Medium & $24 \mathrm{~h}$ & $37^{\circ} \mathrm{C}$ & No & Not shaked & $3 \mathrm{M}$ sodium acetate & B & Poor \\
\hline 11. & Medium & $24 \mathrm{~h}$ & $37^{\circ} \mathrm{C}$ & No & Not shaked & $3 \mathrm{M}$ sodium acetate & B & Not detected \\
\hline 12. & Medium & $24 \mathrm{~h}$ & $37^{\circ} \mathrm{C}$ & No & Not shaked & $3 \mathrm{M}$ sodium acetate & $\mathrm{B}$ & Not detected \\
\hline 13. & Medium & $24 \mathrm{~h}$ & $37^{\circ} \mathrm{C}$ & No & Not shaked & $3 \mathrm{M}$ sodium acetate & B & Not detected \\
\hline 14. & Medium & $24 \mathrm{~h}$ & $37^{\circ} \mathrm{C}$ & No & Not shaked & $3 \mathrm{M}$ sodium acetate & B & Poor \\
\hline 15. & Medium & $24 \mathrm{~h}$ & $37^{\circ} \mathrm{C}$ & No & Not shaked & $3 \mathrm{M}$ sodium acetate & B & Poor \\
\hline 16. & Control & \multicolumn{7}{|c|}{ Bromophenol blue loading dye } \\
\hline
\end{tabular}

A: phenol: chloroform: isoamyl alcohol (25:24:1); B: phenol: chloroform (25:24)
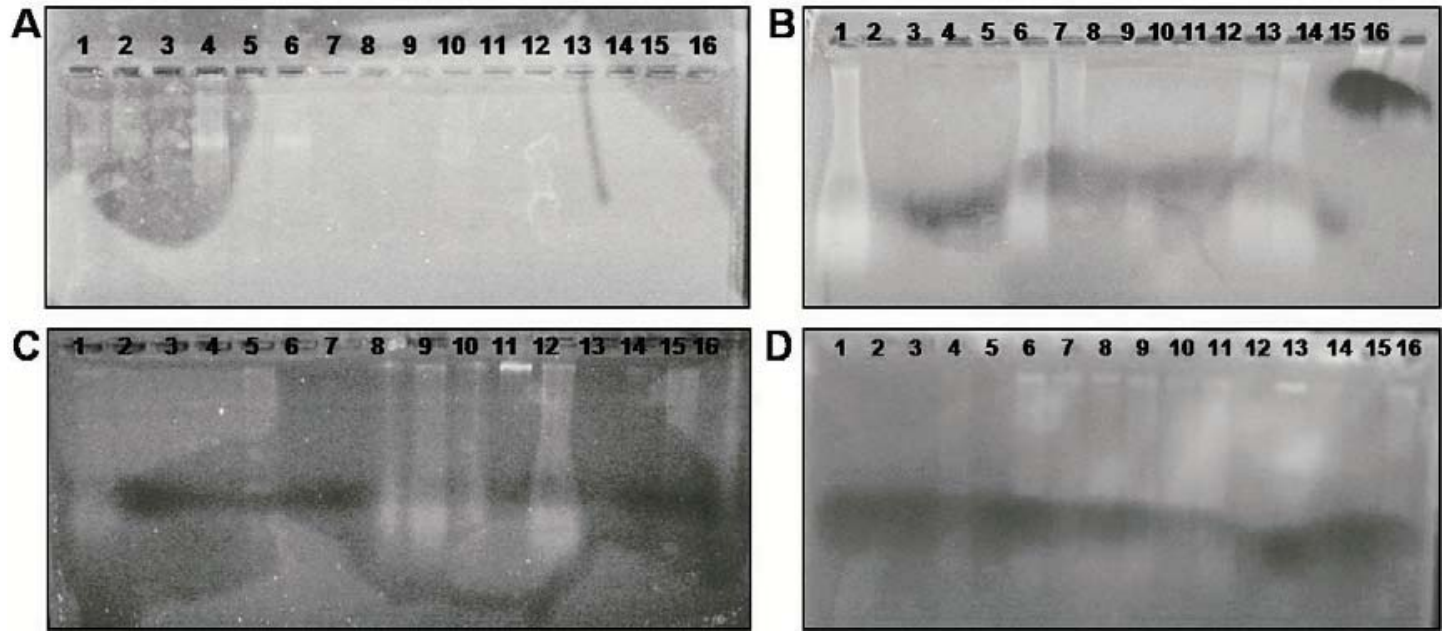

Fig. 2A-2D. Restriction analysis of isolated genomic DNA of Lophura leucomelana feathers. (A) shows endorestricition with HindIII enzyme; (B) restriction analysis with PstI; (C) Genomic DNA restricted with both HindIII and PstI; (D) Indicates the DNA restriction with BamHI. 
Pst 1, BamHI and HindIII (Vivantis) at $37{ }^{\circ} \mathrm{C}$ for overnight. Examination of the reacted DNA with single restriction enzyme was observed by $2 \%$ agarose gel electrophoresis and indicated the complete cleavage, as seen by disappearance of the genomic DNA band and uniform smear of cleaved DNA (Chapaval et al., 2008; Saiki et al., 1985), (Fig. 2A-2D). On the other hand when two restriction enzymes were used in combination then incomplete digestion was observed (Fig. 2C). Similar results were also observed when genomic DNA was treated with only BamHI (Fig. 2D). The protocol described here has the advantage that the quantity and quality of the DNA preparation can be easily visualized by agarose gel electrophoresis and ethidium bromide staining because the DNA yield is of sufficient quantity and the DNA remains double stranded.

\section{Conclusion}

Results shows that the newly described method of DNA extraction is a rapid, simple, useful and reproducible method for small scale isolation of high quality of genomic DNA from the fresh or newly plucked feathers for the purpose of evolutionary relationships and other genomic investigations. This extracted genomic DNA will be used as a template for the polymerase chain reaction to isolate the growth promoting gene, for the sequence analysis and the finding of phylogenetic relationship among these Galliformes in future project. Finally, the modified protocol increase laboratory efficiency and safety.

\section{Acknowledgement}

Authors are thankful to Department of Wildlife and Fisheries of Azad Jammu \& Kashmir for their help in sample collection from Captive Breeding Center Pattika, Muzaffarabad for the current study.

\section{References}

Alleman, A.R. 1996. Molecular tools for the diagnosis of animal diseases. Veterinary Clinics of North America: Small Animal Practice, 26: 1223-1237.

Andleeb, S., Imran, A., Muhammad, S.S., Rob, W.B., Shahid, M. 2010a. Heterologous expression of $\beta C 1$ of Chili leaf curl virus in Pichia pastoris. African Journal of Biotechnology, 9: 8023-8031.

Andleeb, S., Imran, A., Aftab, B., Rob, W.B., Shahid, M. $2010 \mathrm{~b}$. Transient expression of $\beta C 1$ protein differentially regulates host genes related to stress response, chloroplast and mitochondrial functions.
Virology Journal, 7: 1-12.

Bricker, J., Bushar, L.M., Reinert, H.K., Gelbert, L. 1996. Purification of high quality DNA from shed skin. Herpetological Review, 27: 133-134.

Chapaval, L., Moon, D.H., Gomes, J.E., Duarte, F.R., Tsai, S.M. 2008. An alternative method for Staphylococcus aureus DNA isolation. Arquivo Brasileiro de Medicina Veterinaria e Zootecnia, 60: 299-306.

Davidson, I., Maray, T., malkinson, M., becker, Y. 1986. Detection of Marek's disease virus antigens and DNA in feathers from infected chickens. Journal of Virological Methods, 13: 231-244.

Del Hoyo, J., Elliott, A., Sartagal, J. 1994. The Handbook of the Birds of the World, II. New World Vultures and Guineafowl, vol. 2, 638 pp., Barcelona; Lynx, Spain.

Delacour, J. 1977. The Pheasants of the World. pp. 241242, $2^{\text {nd }}$ edition, World Pheasant Association and Spur Publications, Hindhead, UK.

Delacour, J. 1949. The Genus Lophura (Gallopheasants). International Journal of Avian Science, 91: 188-220.

Eggert, L.S., Eggert, J.A., Woodruff, D.S. 2003. Estimating population sizes for elusive animals: the forest elephants of Kakum National Park, Ghana. Molecular Ecology, 12: 1389-1402.

Eguchi, T., Eguchi, Y. 2000. High yield DNA extraction from the snake cast-off skin or bird feathers using collagenase. Biotechnology Letters, 22: 1097-1100.

Gerloff, U., Schlotterer, C., Rassmann, K., Rambold, I., Hohmann, G., Frutth, B., Tautz, D. 1995. Amplification of hypervariable simple sequence repeats (microsatellites) from excremental DNA of wild living Bonobos (Pan paniscus). Molecular Ecology, 4: 515-518.

Goossens, B., Waits, L.P., Taberlet, P. 1998. Plucked hair samples as a source of DNA: reliability of dinucleotide microsatellite genotyping. Molecular Ecology, 7: 1237-1241.

Hauge, J.G. 1997. From molecular genetics to diagnosis and gene therapy. Advances in Veterinary Medicine, 40: $1-49$.

Hausknecht, R., Gula, R., Pirga, B., Kuehn, R. 2007. Urine a source for noninvasive genetic monitoring in wildlife. Molecular Ecology Notes, 7: 208-212.

Johnsgard, P.A. 1999. The Pheasants of the World: Biology and Natural History. 398 pp., $2^{\text {nd }}$ edition, Smithsonian Institution Press, Washington D.C., USA.

Johnsgard, P.A. 1986. The Pheasants of the World. 
pp. 287-295, Oxford University Press, Oxford, UK. Kimball, R.T., Braun, E.L., Zwartjes, P., Crowe, T.M., Ligon, J.D. 1999. A molecular phylogeny of the pheasants and partridges suggests that these lineages are not monophyletic. Molecular Phylogenetic Evolution, 11: 38-54.

Lucentini, L., Caporali, S., Palomba, A., Lancioni, H., Panara, F. 2006. A comparison of conservative DNA extraction methods from fins and scales of freshwater fish: a useful tool for conservation genetics. Conservation Genetics, 7: 1009-1012.

McGowan, P.J.K., Panchen, A.L. 1994. Plumage variation and geographical distribution in the Kalij and Silver Pheasants. Bulletin of the British Ornithologists'Club, 114: 113-123.

McGrew, W.C., Ensminger, A.L., Marchant, L.F., Pruetz, J.D., Vigilant, L. 2004. Genotyping aids field study of unhabituated wild chimpanzees. American Journal of Primatology, 63: 87-93.

Morin, P.A., Chambers, K.E., Boesch, C., Vigilant, L. 2001. Quantitative polymerase chain reaction analysis of DNA from noninvasive samples for accurate microsatellite genotyping of wild chimpanzees (Pan troglodytes verus). Molecular Ecology, 10: $1835-1844$.
Natialia, B., Olga, F., Armand, S. 2001. Isolation of genomic DNA from feathers. Journal of Veterinary Diagnostic Investigation, 13: 162-164.

Nota, Y., Takenaka, O. 1999. DNA extraction from urine and sex identification in birds. Molecular Ecology, 8: 1237-1238.

Randi, E., Lucchini, V. 1998. Organisation and evolution of the mitochondrial DNA control region in the avian genus Alectoris. Journal of Molecular Evolution, 47: 449-462.

Saiki, R.K., Scharf, S., Faloona, F., Mullis, K.B., Horn, G.T., Erlich, H.A., Arnheim, N. 1985. Enzymatic amplification of b-globulin genomic sequences and restriction site analysis for diagnosis of sickle cell anemia. Science, 230: 1350-1354.

Schmaltz, G., Somers, C.M., Sharma, P., uinn, J.S. 2006. Non-destructive sampling of maternal DNA from the external shell of bird eggs. Conservation Genetics, 7: 543-549.

Taberlet, P., Bouvet, J. 1991. A single plucked feather as a source of DNA for bird genetic studies. The Auk, 108: 959-960.

Tikel, D., Blair, D., Marsh, H.D. 1996. Marine mammal faeces as a source of DNA. Molecular Ecology, 5: 456-457. 